\title{
Mesangial Proliferative Glomerulonephritis
}

National Cancer Institute

\section{Source}

National Cancer Institute. Mesangial Proliferative Glomerulonephritis. NCI Thesaurus.

Code C35445.

A focal inflammation of glomeruli secondary to mesangial cell proliferation and matrix deposition within the mesangium. 